\title{
Comment on "On History and Policy: Time in the Age of Neoliberalism"
}

\author{
Wolfgang Streeck \\ Director, Max Planck Institute for the Study of Societies, Cologne, Germany \\ ws@mpifg.de
}

\begin{abstract}
It is not only economics that needs to regain a sense of history but also much of social science. Like economists social scientists need to liberate themselves from a Newtonian clockwork view of the world, and from a view of social reality as an emanation and arbitrary illustration of universal laws governing social life in general. Social science needs a renewed awareness of its origins in a systematic theory of historical social development and evolution, of endogenous social dynamics, and of directionality of social and institutional change, especially in contemporary capitalism, free from historical teleology and economic determinism.
\end{abstract}

\section{Keywords}

development - evolution - trends and events - directionality - institutional change capitalism - political economy

Reading Boldizzoni's brilliant essay I was struck by the similarity between what he sees as the suitable role of the historian and what I think is that of the social scientist. I am also impressed with the parallels between what Boldizzoni has to say on economics and what I believe needs to be said on the social sciences proper, in particular on sociology and political science. The verdict is the same, and so are the practical conclusions on our disciplines' potential contribution, if at all, to the politics of capitalist democracies and societies in their current condition.

Anticipating what I am about to say, I think the only future for the social sciences in which they can hope to escape from their increasing irrelevance is 
in going back to the critical juncture where they abandoned "the economy" to the economists, and avoid getting lost once more in the blind alley into which they have since allowed themselves to be led. They cannot hope on much support from the economists in this; standard economics will defend its turf with the full arsenal of demagogic tricks at its disposal. The natural allies of a renewal of the social sciences, in addition to the hopeless minority of truly heterodox economists, are historians with a sense of history, like Boldizzoni, not least since they obviously know much better than we do what went wrong and when with social science. What needs to be accomplished is nothing less than bringing the economy back as a central subject into a social science equipped with a renewed awareness of the deep historicity of its subject world, a social science willing to return to its foundational question of how that world changes and what drives its change. To reincorporate the economy into a valid account of the social world of today, social scientists need to be enlightened by economic historians on what has gone wrong with contemporary economics, because much the same pathologies have also affected contemporary social science.

What does it mean to have a sense of history? And why does social science need one? Having a sense of history as a social scientist means knowing that what one sees is embedded in a continuing chain of events - that what we observe and live in is a transient and contingent world selected in the past from a universe of alternative worlds by human agency, intentionally or not, in combination with fate. The world that is ours, the really existing world, has a past and a future, lined up in time and connected through the present, with previous events and structures causing, or more precisely: conditioning, subsequent ones. A sense of history also means understanding that the present world has a beginning as well as an end, hard as they may be to identify, and that it is unique - not just in the sense that it is the only world that is, but also because it is located in historical time and subject to its passing: you cannot, as famously noted by Heraclitus of Ephesus, step twice into the same river.

Contemporary social science, I claim, including where it deals with social and institutional change, has all too often sacrificed its sense of history on the altar of nomothetic elegance and parsimony. The founders of the social sciences in the nineteenth century had as their subject the dynamic transition of their societies from traditionalism to industrialism, capitalism, modernity: a world-historical transformation that they tried to understand in its global consequences. Accounting for the dynamic unfolding of ever new, hitherto unimaginable, surprising properties of a no longer stationary society required a reconstruction of historical observables in terms of general concepts identifying the driving forces that underlay the concrete, specific, unique development of post-traditional social structures. This gave rise to historical accounts 
drawing on concepts such as evolution, progress, liberation, revolution, modernization and the like, conceived to model the operation of a social-historical logic as revealed in patterned social change proceeding in and over time.

Roughly a century later, however, and particularly in the apparent posthistoire of the three decades after the Second World War, social science succumbed to a tendency, reinforced undoubtedly by parallel developments in the natural sciences and the emerging economics of the time, to treat the existing historical world as a random illustration of general principles, formal rather than substantive and abstracted from time and place, whose empirical manifestations are of interest not for their uniqueness but only for what they have in common with other manifestations of the same category. References to time and place, to names, to what Weber following Rickert had called "historical individuals", were dropped in favor of analytical concepts applicable to entire classes of cases. History was sliced up, its emanations carved out of historical time, with their past reduced to an accidental, contingent set of "independent variables". Analytical property spaces became timeless, and conceptual universalism drove out historical specificity. The real word, once seen as the result of an interaction in time and place of "rationality, institutions, and human culture" (Boldizzoni), was treated as an illustration of general laws, exchangeable in principle for a different world without making a difference for the laws governing both the contingently real and the contingently non-real.

In the process, social science was effectively cleansed of its early language of evolution, development and historical directionality, of endogenous causes driving societies over time and into their futures, of systemic disequilibria requiring and resulting in a continuous re-shaping of historical social structures. The equivalent in the social sciences of economics' "Newtonian clockwork" view of the economy (Boldizzoni) was a concept of society as intrinsically stationary and in equilibrium, upset only exogenously and accidentally by random shocks, to be subsequently restored by built-in mechanisms of negative feedback. Different social phenotypes were no more than different expressions of an identical genotype - variations on an unchangeable theme. There was no systematic reason in postwar social science, nothing generically or historically social, why societies should not forever remain the way they were. Historical agnosticism - fed by fear of being accused of theoretical determinism, of adherence to a "philosophy of history", essentially meaning being too close to Marxism - finally triumphed when at last "modernization theory", including its postwar American capitalism-equals-democracy mutation, was expelled from legitimate social science.

Contemporary social science is historically agnostic even where it studies institutional change. Where in the nineteenth century change was conceived as change in capitalism, today the focus is on formal properties of change 
out of context, as it may take place anywhere and at any time. Conceptually, where there used to be directionality, or even development, we now find "path dependence" as a weak substitute. Other formal concepts waiting to be filled with historical substance, but only for illustrative purposes, are layering, drift, conversion, disruption, exhaustion and the like. As a political scientist I was involved in the construction of these concepts, together with a group of colleagues who rightly felt a need for a more dynamic perspective on institutions (Streeck and Thelen 2005a). Not that the results of our work did not add to our knowledge or our analytical toolkit - as witnessed by their wide reception and frequent adoption. We argued, I believe: convincingly, that institutional change was omnipresent as there could be no perfect replication of extant social structures. But this told us nothing about the concrete causes and the driving forces of change as our typologies took change out of its historical context and cut it out of the pattern of events through which it inevitably but ultimately randomly advanced. Time figured, but only chronological time (how long it takes for change to happen and be completed), not historical time as it progresses in a unique, $\mathrm{N}=1$ world.

Significantly, when looking for examples in contemporary political economy to illustrate our typology, we found only cases where change went in the broad direction of liberalization, away from the institutions of the postwar settlement to institutions belonging to an emerging new contractual, marketdriven social order, developing mostly slowly, without dramatic breaks, and freely drawing on the full panoply of types of incremental yet fundamental change that we had identified (Streeck and Thelen 2005b). Why this was so why change was not random, and whither the remarkable equidirectionality of political-economic change in late twentieth and twenty-first century capitalism - our historically agnostic approach was unable to tell us, even though this was arguably the by far most important question. To me, the only way this could be remedied was by further developing what we had considered a theory of institutional change into a theory of institutional change in capitalism as it outgrows the "embedded liberalism" regime of the postwar era (Streeck 2010).

Historical agnosticism is not just a problem in the social sciences, though. While much of contemporary social science tends to reduce reality to a "case" exemplifying a general principle, contemporary historians, apparently afraid of being accused of distorting "the facts" in the service of general theories or political ideologies, often confess to a nominalist worldview in which historical observations stand only for themselves. ${ }^{1}$ To me this is as devoid of a sense of

1 In fact, if general or historically specific theories of social change are referenced at all, the case at hand is preferably and often triumphantly presented as a local deviation, ultimately 
history as is the nomothetic universalism of standard social science, including of course standard economics. What good is a historiography that knows only events and no trends; only trees and no forest; only agency and no structure; only exogenous causes and no endogenous dynamics; only observations, no theory; only shocks, no regularities? Surprisingly, just as social scientists, historians all too often extricate their subjects from their historical context, under pressure to insist that what they find to be historical reality never quite fits a broader pattern of historical development or evolution. "Respect for the otherness of the past" (Boldizzoni) notwithstanding, historical nihilism of this sort may end up with a general message like "There is no new thing under the sun" (The Book of Kohelet 1,9 ). ${ }^{2}$ It is true, as Boldizzoni points out, that historians, unlike economists and modern social scientists, produce not just snapshots but films, and this is much to their credit. But why watch a movie that lacks a story - one that simply lines up stills, pasted together like a string of random numbers?

As a social scientist, I consider it essential that social science avail itself of the support of historians who have not abandoned their sense of history. Following up on my work on institutional change, when trying to pull together what I knew about the transformation of the German political economy in the last third of the twentieth century (Streeck 2009), I realized that a further refinement of our analytical typology would not serve the purpose, and neither would static equilibrium models like those of the "varieties of capitalism" school (Hall and Soskice 2001). ${ }^{3}$ What I had to account for was a complex, multifaceted bundle of processes of social-institutional change, driven from within while modified from without, exhibiting a logic that not only cut across sectors but was present in other, similar countries as well. In the period I looked at, that is to say, directions of change were far from randomly

suggesting that there are no rules but only exceptions, as though it was the task of the historian to demonstrate that generalization on historical trends and common tendencies is futile, to be discouraged in the name of the superior dignity of the specific.

2 This seems particularly true for economic history, much of which seems to see its mission in demonstrating the universality of capitalism and its guiding model of social action, that of homo oeconomicus (or, among accommodating social scientists, rational choice). Regardless of time and place, economic "laws", as stipulated by neoclassical Newtonian theory, apply. This is to me as ahistorical as its counterpart, nominalist exceptionalism. As Goethe has it in Faust: Du siehst mit diesem Trank im Leibe / Bald Helenen in jedem Weibe (With that drink in your body, well then / All women will look to you like Helen).

3 I apologize for dwelling so extensively on my own work - it is because I know it better than the work of others, and also because I can use it to illustrate a learning process that I feel was so enlightening that I wish I would have undergone it much earlier. 
distributed between institutions; while types of change differed by sectors and occasion, this was not true for the telos of change, which basically was that of a historical process of capitalist development and capitalist advance, fully understandable only in terms of the fundamental categories of traditional political economy, like market, state, class, interest, power and the like. For the time and place under study, clearly the appropriate conceptual apparatus was one emphasizing, not the "varieties", but the commonalities of capitalism, one capable of reconstructing the notion of a capitalist society, not just economy, as an interactive complex of institutions and sectors bound together in a historical movement of dynamic expansion.

The experience of the crisis of 2008 strongly confirmed this conclusion. Like Boldizzoni, and following much the same Heraclitian reasoning, I found it basically useless to compare the Great Recession to the Great Depression, in the model-building, system-theoretical, ahistorical fashion economists somehow believe to be "scientific". In the book that I wrote about the "financial crisis" (Streeck 2014), I placed it in a historical sequence of crises that began with the global inflation of the 1970s, continued with the dramatic increase in public debt during the 1980s, led to first attempts at fiscal consolidation and its compensation by a global rise in private debt, and has after 2008 manifested itself in a steep expansion of central bank asset holdings. Intertwined with this succession of temporary fixes to the distributional conflicts inherent in capitalism that lasted only until they turned from solutions into problems and had to be replaced with new fixes - intertwined with it was a historical transformation of the tax state of old into a debt state and, since the 1990s and today more than ever, into what I call a consolidation state. This, in turn, was linked to a shift of the arena of distributional conflict from the labor market to the electoral politics of the welfare state to the capitalmarkets and the financial system, and from there to international financial diplomacy and the decision-making bodies of the large central banks. Moreover, parallel to the three strands of institutional change - the crisis sequence, the transformation of public finance, the upward shift of conflict arenas - economic and social inequality increased sharply in the countries of advanced capitalism, growth rates declined, and overall levels of indebtedness, private as well as public, went up steadily.

In the book, I account for this dynamic in terms of basic underlying disparities in power and conflicts of interest, as constitutive for a capitalist social order. Among other things, these manifest themselves in society being subject to fundamental instability in both economy and polity, where a political equilibrium is under democratic conditions attainable only at the price of an economic disequilibrium, which can typically be remedied only by accepting a political disequilibrium. Governments in a political economy of this sort face 
a profound dilemma forcing them to shuttle back and forth between two kinds of crisis, in the hope that they will not at some point occur simultaneously. Chasing from one fix to the next, governments drive the democratic-capitalist crisis sequence forward, in a complex interaction, cooperative and contentious at the same time, with capital on the one hand and labor on the other. A problem for historians may be that the nature of this process is such that it need not entirely flow from the manifest intentions of actors traceable in archival research. Certainly the logic of development that I have found, for example the transformation of the tax state into a debt state and then a consolidation state, was and is an emergent one: one that in order to come about does not require forward planning by the actors involved. One could say (cautiously, so as to avoid shifting from an untenable voluntarism into an equally untenable determinism) that the underlying problem structure, including the divergent interests of the relevant parties, as endowed with situationally changing power resources, limited actors' repertoire of action and invention in the same way as did the contingent circumstances and precedent histories of the respective crises. How do such patterns arise? How much or how little intentionality do they need, and why? How do structure, agency and contingency work together in producing them? Why can we recognize the dynamic patterns of capitalist political-economic history in retrospect but cannot predict their evolution as we look forward into the future? Apparently social scientists today must return to very old questions, leaving behind the clockwork imagery of modern economics together with its technocratic promises, and recovering a sense of history as preserved by some although not all historians. As of now we have not got very far in this respect, and without the advice and assistance of historians interested in more than just events we may never make the progress we need in order, following Boldizzoni, to become capable of enlightening citizens instead of trying in vain to advise their governments.

\section{References}

Hall, Peter A. and David Soskice, 2001. An Introduction to Varieties of Capitalism. In: Hall, Peter A. and David Soskice, eds., Varieties of Capitalism: The Institutional Foundations of Comparative Advantage. Oxford: Oxford University Press, 1-68.

Streeck, Wolfgang, 2009. Re-Forming Capitalism: Institutional Change in the German Political Economy. Oxford: Oxford University Press.

, 2010. Institutions in History: Bringing Capitalism Back In. In: Campbell, John et al., eds., Handbook of Comparative Institutional Analysis. Oxford: Oxford University Press, 659-686.

JOURNAL OF THE PHILOSOPHY OF HISTORY 9 (2015) 33-40 
, 2014. Buying Time: The Delayed Crisis of Democratic Capitalism. London and New York: Verso Books.

Streeck, Wolfgang and Kathleen Thelen, eds., 2005a. Beyond Continuity: Institutional Change in Advanced Political Economies. Oxford: Oxford University Press.

, 2005b. Introduction: Institutional Change in Advanced Political Economies. In: Streeck, Wolfgang and Kathleen Thelen, eds., Beyond Continuity: Institutional Change in Advanced Political Economies. Oxford: Oxford University Press, 1-39. 